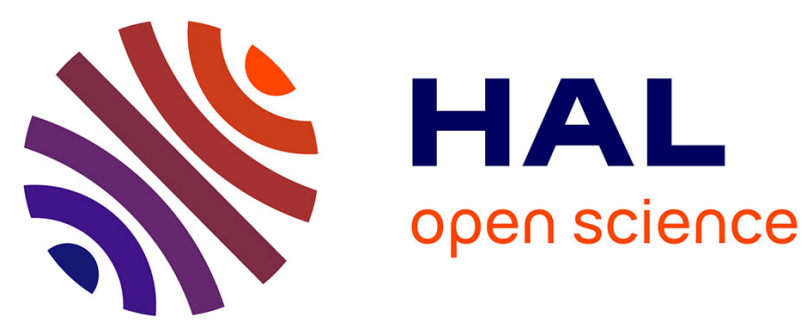

\title{
The Influence of Step Length to Step Frequency Ratio on the Perception of Virtual Walking Motions
}

\author{
Benjamin Niay, Anne-Hélène Olivier, Julien Pettré, Ludovic Hoyet
}

\section{To cite this version:}

Benjamin Niay, Anne-Hélène Olivier, Julien Pettré, Ludovic Hoyet. The Influence of Step Length to Step Frequency Ratio on the Perception of Virtual Walking Motions. MIG 2019 - 12th annual ACM SIGGRAPH conference on Motion, Interaction and Games, Oct 2019, Newcastle upon Tyne, United Kingdom. ACM Press, Proceeding MIG '19 Motion, Interaction and Games, pp.1-2, 10.1145/3359566.3364687 . hal-02378300

\section{HAL Id: hal-02378300 https://hal.science/hal-02378300}

Submitted on 5 Dec 2019

HAL is a multi-disciplinary open access archive for the deposit and dissemination of scientific research documents, whether they are published or not. The documents may come from teaching and research institutions in France or abroad, or from public or private research centers.
L'archive ouverte pluridisciplinaire HAL, est destinée au dépôt et à la diffusion de documents scientifiques de niveau recherche, publiés ou non, émanant des établissements d'enseignement et de recherche français ou étrangers, des laboratoires publics ou privés. 


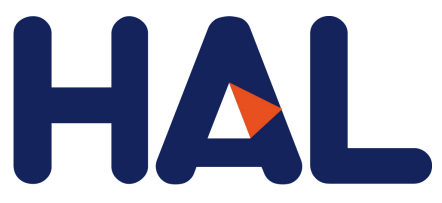

archives-ouvertes

\title{
The Influence of Step Length to Step Frequency Ratio on the Perception of Virtual Walking Motions
}

\author{
Benjamin Niay, Anne-Hélène Olivier, Julien Pettré, Ludovic Hoyet
}

\section{To cite this version:}

Benjamin Niay, Anne-Hélène Olivier, Julien Pettré, Ludovic Hoyet. The Influence of Step Length to Step Frequency Ratio on the Perception of Virtual Walking Motions. Motion, Interaction and Games, Oct 2019, Newcastle upon Tyne, United Kingdom. pp.1-2, 10.1145/3359566.3364687 . hal-02378300

\section{HAL Id: hal-02378300 \\ https://hal.archives-ouvertes.fr/hal-02378300}

Submitted on 5 Dec 2019

HAL is a multi-disciplinary open access archive for the deposit and dissemination of scientific research documents, whether they are published or not. The documents may come from teaching and research institutions in France or abroad, or from public or private research centers.
L'archive ouverte pluridisciplinaire HAL, est destinée au dépôt et à la diffusion de documents scientifiques de niveau recherche, publiés ou non, émanant des établissements d'enseignement et de recherche français ou étrangers, des laboratoires publics ou privés. 


\title{
The Influence of Step Length to Step Frequency Ratio on the Perception of Virtual Walking Motions
}

\author{
Benjamin Niay \\ Anne-Helene Olivier \\ Julien Pettre \\ Ludovic Hoyet \\ Inria, Univ Rennes, CNRS, IRISA, M2S
}

\section{CCS CONCEPTS}

- Computing methodologies $\rightarrow$ Animation.

\section{KEYWORDS}

Perception, Walk Ratio, Motion Capture, Animation, Virtual Human

\section{ACM Reference Format:}

Benjamin Niay, Anne-Helene Olivier, Julien Pettre, and Ludovic Hoyet. 2019. The Influence of Step Length to Step Frequency Ratio on the Perception of Virtual Walking Motions. In Motion, Interaction and Games (MIG '19), October 28-30, 2019, Newcastle upon Tyne, United Kingdom. ACM, New York, NY, USA, 2 pages. https://doi.org/10.1145/3359566.3364687

\section{INTRODUCTION}

The realism of Virtual Human (VH) motions, which populate virtual worlds, is an important requirement for entertaining applications. Controlling VH so that they can walk naturally is therefore particularly important. However, humans walk with different speeds and styles [Hoyet et al. 2013] because of individual differences, which is seldom taken into account in current virtual environments. In particular, walking is typically animated by controlling only the desired speed, which itself depends on two parameters: step length and frequency. The ratio of theses two parameters is called the Walk Ratio [Sekiya et al. 1996]. While influenced by individual characteristics such as gender, morphology or age, this ratio has been shown to be an invariant parameter of walking naturally adopted by people, and which minimises energy expenditures. In this pilot study we therefore explore how the perceived naturalness of blended animations is influenced by these two parameters.

\section{MOTION CAPTURE}

We recorded multiple walking motions from 4 actors (2F, 2M) using a Xsens MVN Link. To measure their individual Walk Ratio at different speeds, they first walked at 5 different freely chosen speeds without constraints on step length and frequency, ranging from a very slow to a very fast walk. Then, they walked using 5 different step lengths, from very small to very long steps. For each step length, they were asked to walk at 5 different step frequencies using a metronome (80, 90, 100, 110 and 120 steps per min). This provided 25 different combinations of (step length, frequency) walking motions. Using the Unity Mecanim Animation System, we constructed a 2D Blend Tree for each actor controlling both the speed and frequency of animations, which then generates new walking animations with the corresponding step length for these parameters.

\section{EXPERIMENT}

We selected 1 male and 1 female VH to display the captured motions. They were scaled according to the height of each corresponding actor, as the morphology of the $\mathrm{VH}$ would otherwise influence the speed and step length of the displayed motions, and therefore the corresponding Walk Ratio. To evaluate the range of frequencies producing natural walking motions for a given speed, we asked participant to adjust the step frequency of virtual characters using a keyboard until they considered the motion to be the most natural. In each trial, 15 participants $(11 \mathrm{M}, 4 \mathrm{~F})$ were presented with 1 of the $4 \mathrm{VH}$, walking at either $0.8,1.0$ or $1.2 \mathrm{~m} / \mathrm{s}$. In total, participants were presented in random interleaved order with 24 conditions: 4 Actors $\times 3$ Walking Speeds $\times 2$ Initializations $(80$ or $120 \mathrm{spm})$ repeated 4 times each. VH were displayed using a typical canonical viewpoint, providing as much information as possible about the studied motions (Figure 1).
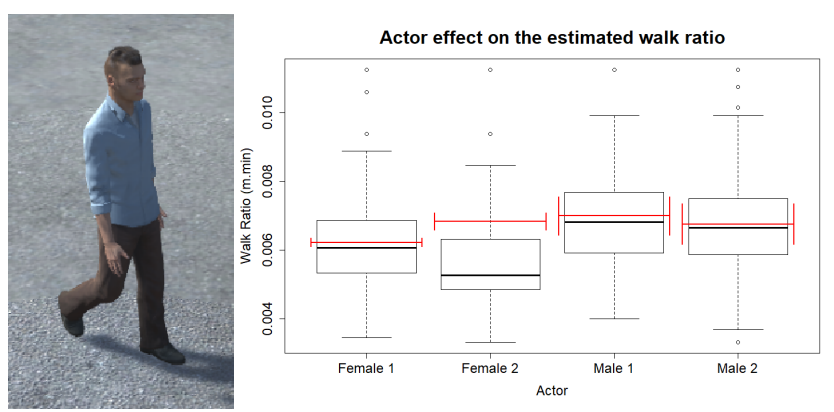

Figure 1: (Left) Male character used in our experiment. (Right) Walk ratios estimated by participants (box plot) and computed from motion capture (red lines) for each actor. 


\begin{tabular}{ccccc} 
Actor & Female 1 & Female 2 & Male 1 & Male 2 \\
$\begin{array}{c}\text { Motion captured } \\
\text { WR (m.min) }\end{array}$ & 0.00623 & 0.00684 & 0.007 & 0.00676 \\
$\begin{array}{c}\text { Estimated } \\
\text { WR (m.min) }\end{array}$ & 0.00619 & 0.00561 & 0.00691 & 0.00673 \\
$\begin{array}{c}\text { p-value } \\
\text { Significantly } \\
\text { difference }\end{array}$ & 0.5718 & 0.00561 & 0.2209 & 0.7225 \\
\hline & No & Yes & No & No
\end{tabular}

\section{RESULTS}

For each actor we computed the walk ratio responses of the participants. We performed a one sample student $t$ Test with the participant responses as sample and the motion captured walk ratio as reference. Results are reported in table 1. For 3 of the 4 actors, no significant differences were found between the motion captured and the estimated walk ratio, indicating that participants were able to identify the walk ratio associated to the actors walk. The last actor (Female 2) presents a significant differences between the estimated and motion captured walk ratio. We hypothesis that this latter result might be induced by the motion capture, as this actor had more variability in her steps than the other participants, especially at higher cadences. We then performed a 3-way Repeated Measure ANOVA (withing subject factors Speed, Actor and Initialization). Our hypothesis were that speed has no effect on the estimated walk ratio whereas gender has an effect, as reported in the literature [Sekiya et al. 1996; Zarrugh et al. 1974]. Our primary results seem to be in agreement with the literature, nonetheless further analysis will be necessary to verify if the results for the Female 2 actor impacts the overall results. Therefore, while this pilot study provides valuable insights about whether step length and frequency can influence the perception of virtual walking motions, we think that several aspects need to be further explored to understand their interdependence.

\section{REFERENCES}

Ludovic Hoyet, Kenneth Ryall, Katja Zibrek, Hwangpil Park, Jehee Lee, Jessica Hodgins, and Carol O'Sullivan. 2013. Evaluating the Distinctiveness and Attractiveness of Human Motions on Realistic Virtual Bodies. ACMTOG 32 (2013), 204:1-204:11.

Noboru Sekiya, Hiroshi Nagasaki, Hajime Itoh, and Taketo Furuna. 1996. The invariant relationship between step length and step rate during free walking. fournal of Human Mouvement Studies 30 (1996), 241-257.

M.Y. Zarrugh, F.N. Todd, and H.J. Ralston. 1974. Optimization of Energy Expenditure during Level Walking. Europ. f. appl. Physiol. 33 (1974), 293:306. 